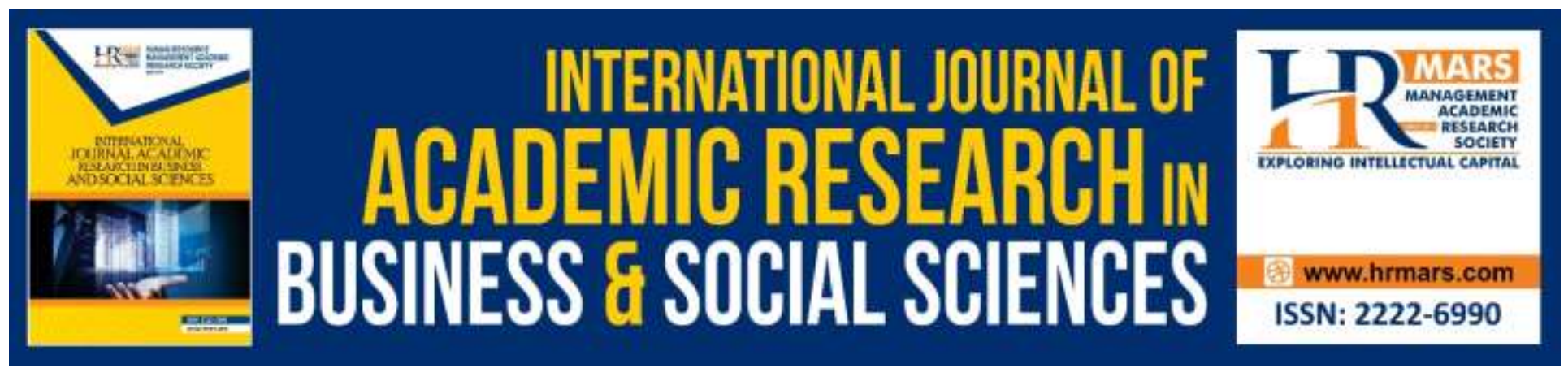

\title{
Personality, Interpersonal Identification and Agent's Performance in Multilevel Marketing Industry (MLM): Preliminary
}

Shaierah Binti Gulabdin, Toh Pei Sung, Stephen Laison Sondoh

To Link this Article: http://dx.doi.org/10.6007/IJARBSS/v10-i3/7061

DOI:10.6007/IJARBSS/v10-i3/7061

Received: 09 February 2020, Revised: 29 February 2020, Accepted: 10 March 2020

Published Online: 31 March 2020

In-Text Citation: (Gulabdin et al., 2020)

To Cite this Article: Gulabdin, S. B., Sung, T. P., \& Sondoh, S. L. (2020). Personality, Interpersonal Identification and Agent's Performance in Multilevel Marketing Industry (MLM): Preliminary. International Journal of Academic Research in Business and Social Sciences, 10(3), 444-452.

Copyright: (C) 2020 The Author(s)

Published by Human Resource Management Academic Research Society (www.hrmars.com)

This article is published under the Creative Commons Attribution (CC BY 4.0) license. Anyone may reproduce, distribute, translate and create derivative works of this article (for both commercial and non-commercial purposes), subject to full attribution to the original publication and authors. The full terms of this license may be seen at: http://creativecommons.org/licences/by/4.0/legalcode

Vol. 10, No. 3, 2020, Pg. 444 - 452

Full Terms \& Conditions of access and use can be found at http://hrmars.com/index.php/pages/detail/publication-ethics 


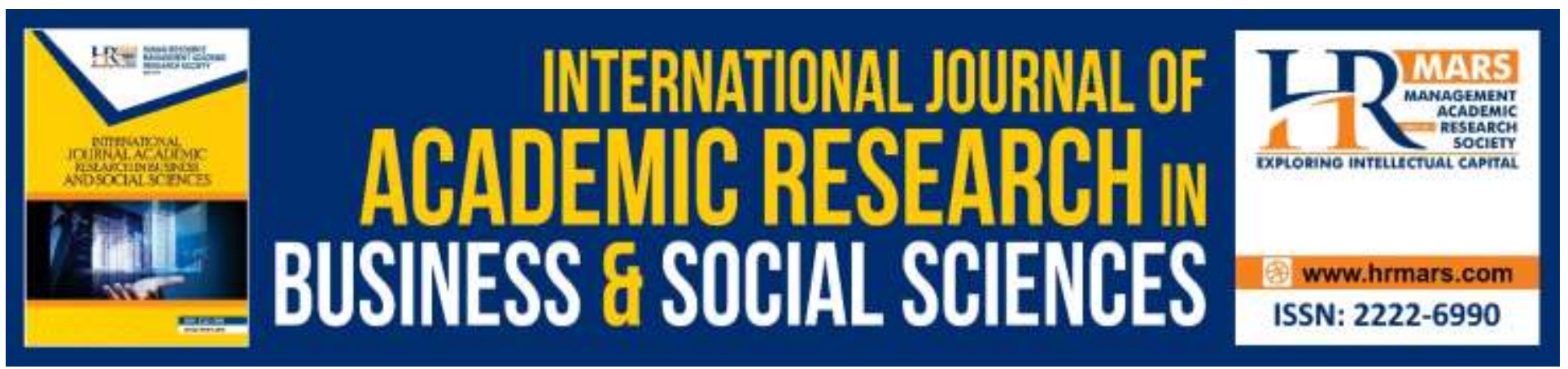

\title{
Personality, Interpersonal Identification and Agent's Performance in Multilevel Marketing Industry (MLM): Preliminary
}

\author{
Shaierah Binti Gulabdin, Toh Pei Sung, Stephen Laison Sondoh \\ Faculty of Business, Economic and Accountancy, Universiti Malaysia Sabah \\ Email: shaierahgulabdin@gmail.com
}

\begin{abstract}
Purpose - This paper aims to explore the influence of personality traits on agent's performance in MLM industry based in Malaysia, taking into consideration the mediating role of interpersonal identification.

Design/methodology/approach - The Big Five Factors (BFF) of personality traits was used in this paper. Previous research and literature is reviewed to establish current practices and point to gaps to be filled to meet the market needs. This paper proposed a framework with interpersonal identification as a mediating factor of agent's performance.

Findings - The Multilevel Marketing (MLM) industry faces challenges in attracting and maintaining agents in their roles. The big five factors alone cannot effectively explain agents. Agent's interpersonal identification can play a significant mediating role in the big five-factor framework in predicting agent's performance. It is important for industry and academia to work collaboratively to educate the general public on the rewards and benefits of working in the MLM industry.

Practical implications - Adopting strategies described in this study may contribute to social change by increasing the success rate among multilevel marketers, thus reducing unemployment, and producing a positive effect on the economy.

Originality/value - This paper adds value and contributes to the MLM industry and academia, as it represents current research and thought processes from both the academic community and the practitioners (sales managers, executives, supervisors, human resources managers). The proposed framework in this paper helps researcher by providing a tool for systematic evaluation and testing of real empirical situation of agent's performance.
\end{abstract}

Keywords: Performance, Multilevel Marketing, Direct Selling, Personality, Interpersonal Identification

\section{Introduction}

The Multilevel Marketing (MLM) industry is a significant contributor to the Malaysian economy. In 
Malaysia, the direct selling industry is expected to contribute RM20 billion to the growth of the Malaysian economy by 2020, says the former Minister of Domestic Trade and Consumer Affairs (MDTCA), Datuk Seri Saifuddin Nasution Ismail. He also added during the $25^{\text {th }}$ Malaysian Direct Distribution Association (MDDA) annual dinner in 2018, Malaysia is listed in the top 10 of global direct selling industry and fourth rank in Asia with China on top, followed by South Korea and Japan. Furthermore, according to Bernama (2018), in 2017 the industry contributed more than RM13 billion sales revenue where the involvement from over 4 million of Malaysians from different society and status. As a matter of fact, the attractiveness of multilevel marketing has several reasons: it seems as an attractive marketing strategy for companies, consumers appreciate buying products from friends and family members, and for distributors, MLM companies offer an easy platform to try an entrepreneurial experience as well as an alternative to get affordable products.

MLM become so popular because it offers everyone the chance of becoming a successful selfemployed opportunity with the freedom to win and little lose. MLM industry is projected to gain attention in the year of 2020 and contribute to the growth of Malaysian economy. Despite its contribution, there are some significant challenges too; the MLM industry in particular depends on access to their reliable and productive labor. This can be validated with the data gained from the direct selling sales' statistics and supported literature. Recent statistics of MLM sales shows there is inconsistency of sales and negative flows where there were 55\% declined in the total sales of MLM business each year (KPDNKK, 2018). Furthermore, attrition rate or drop-out rate of distributors is also very high in this industry (Loke \& Ilham, 2015). Hence, the aim of this paper is:

- to explore the influence of personality traits on agent's performance in MLM industry based

in Malaysia, taking into consideration the mediating role of interpersonal identification.

There was previous study has shown that personality is important to a salesperson. But so far, there were less attention given to this factor towards MLM agents specifically in Malaysia. Besides, interpersonal identification has been acknowledged as one of the factors that influenced performance. However, the context so far lies on the organizational identification which neglecting the interpersonal identification processes in the relational level (Mahlamaki et al., 2018). Particularly, having numerous and effective agents are the key to their business success. In order to enhance the network relationship among the agents of MLM and improve their agent's performance, they require the existing agents to recruit new agents in order to grow the business, ensuring the right agent with strong personality of new agents are necessary to influence their performance to be successful.

\section{Personality and Agent's Performance}

Contemporary researchers in psychology have unanimously converged on the opinion that there are five underlying personality traits or characteristics possess by individuals. The testimony as regards to this theory has been developing for more than five decades. This assertion begins with the work of D. W. Fiske (1949) which was subsequently extended upon by several other researchers (Norman, 1967; Smith, 1967; Goldberg, 1981; McCrae \& Costa 1987), all of which premised that the big five personality traits could be used to predict employee job performance. However, researchers do not always agree on the exact characteristics for each dimension, even though there is a substantial body of literature buttressing this model of personality. Notwithstanding, the five-dimension categories are usually illustrated as Extraversion, Agreeableness, Conscientiousness, Emotional Stability, and Openness to Experiences. 
INTERNATIONAL JOURNAL OF ACADEMIC RESEARCH IN BUSINESS AND SOCIAL SCIENCES Vol. 10, No. 3, March, 2020, E-ISSN: 2222-6990 @ 2020 HRMARS

Many empirical findings in psychology, have so far established that human personality invariably reflect his or her behavior generally and specifically in job related behavior. Performance as an outcome of behavior is proven to be predicted by individual personality characteristics. In their meta-analysis of personality and job performance, Hurtz et al (2000) revisited the big five factor and find substantive argument for the relationship between the big five personality traits dimension and job performance, while another research has specifically confirmed the predictive validity of the big five personality traits toward predicting overall salespeople's performance (Thoresen et al., 2004). The big five model remains the most dominant model for measuring personality, which is why it was selected for use in the present study. Personality embraces moods, attitudes, and opinions and is most clearly expressed in interactions with other people (Janjua, 2016). Besides, it includes behavioral characteristics, both inherent and acquired, that distinguish one person from another and that can be observed in people's relations to the environment and to the social group. Roberts and Woodman (2017) suggested that researchers need to give more attention to personality in relation to performance by using the big five factors as well.

MLM challenges or issues have, according to a number of authors, become the focus of concern. The researcher's review includes recent news, academics papers, articles from previous researches, and also from the Malaysia's government plan on MLM industry. Although the researcher's attention focused on the Malaysia perspective, given the global nature of MLM industry the researcher also incorporated articles with an international scope to validate the fact that issues related to the MLM industry challenges are of general interest. This approach also helped the researcher to demonstrate that the discussion regarding attracting and retaining a productive agent is well grounded in existing literature as one of the challenges in existing literature on a scale that extends beyond the Malaysian borders.

MLM is thriving businesses in the global and national market. In Malaysia, the direct selling industry has a turnover of US\$4.7 Billion in 2014, and it is ranked ninth in the global selling markets with total of 4.3 million salespeople or $14.3 \%$ of the population involved in direct selling (World Federation of Direct Selling association, 2015). Kwang (2014) cited that as of August 1, 2014, there are 443 direct sales licenses issued by the Ministry of Domestic Trade, Co-operatives and Consumerism in Malaysia. Hence, there are many direct selling companies to opt for by people who are interested to join direct selling business. Further to that, attrition rate or drop-out rate of distributors is also very high in this industry (Loke \& Ilham, 2015). Hence, it is compelling to know what factors influence and motivate individuals to become dealer in direct selling companies.

There are relevant data about the statistics of direct selling's companies in Malaysia that annually published by the Ministry of Domestic Trade, Co-operatives and Consumerism or also known as Kementerian Perdagangan Dalam Negeri, Koperasi dan Kepenggunaan (KPDNKK). It published the total number of licensed direct selling companies based on the statistics which includes the MLM Company in Malaysia. The analysis of data presented here affords an overview of the industry including the marketing plan's division such as Multilevel Marketing (MLM), Single-level Marketing (SLM), and SLM and Mail Order (MO) total sales from the year of 2012 until 2018.

The data after probing to the MLM Company showed that there is an inconsistency and unsteady growth in the sector in the aforementioned years. It shows that there are negative flows where there were $55 \%$ declined in the total sales of MLM business each year (KPDNKK, 2018). This has shown the need to take more attention and focus on the MLM industry expansion. In order to 
INTERNATIONAL JOURNAL OF ACADEMIC RESEARCH IN BUSINESS AND SOCIAL SCIENCES Vol. 10, No. 3, March, 2020, E-ISSN: 2222-6990 @ 2020 HRMARS

ensure the development of the MLM industry's movement each year according to the plan, action plan Phase 3 (2019 - 2020) that was introduced by the Malaysian government under 2013 - 2020 Pelan Hala Tuju Industri Jualan Langsung document by KPDNKK needs to be referred to;

Phase 3 (2019 - 2020)

Reputation Improvement and Performance Cultivation

\begin{tabular}{|c|c|c|}
\hline Action & Developer & Time Frame \\
\hline $\begin{array}{l}\text { Prepare relevant career path in order to } \\
\text { develop the industry to become the career } \\
\text { of choice for primary income. }\end{array}$ & $\begin{array}{l}\text { Direct Selling } \\
\text { Association }\end{array}$ & $\begin{array}{l}\text { - } 2019 \text { : } \\
\text { S1 }\end{array}$ \\
\hline $\begin{array}{l}\text { Ensure the direct selling industry in Malaysia } \\
\text { adhere to jurisdiction the demands through } \\
\text { independent controlling. }\end{array}$ & $\begin{array}{l}\text { Direct Selling } \\
\text { Association }\end{array}$ & $\begin{array}{l}\text { - } 2019 \text { : } \\
\text { S2 }\end{array}$ \\
\hline $\begin{array}{l}\text { Make Malaysia as a centre of regional } \\
\text { excellence and to become an exemplary } \\
\text { country in excellent business practice for the } \\
\text { direct selling industry. }\end{array}$ & $\begin{array}{ll}- & \text { KPDNKK } \\
\text { - } & \text { Direct Selling } \\
& \text { Association }\end{array}$ & $\begin{array}{ll}\text { - } & 2019: \\
& \text { S4 }\end{array}$ \\
\hline $\begin{array}{l}\text { Ensure the industry is growing consistently } \\
\text { and become a contributor for the increase in } \\
\text { Gross National Income (GNI). }\end{array}$ & - KPDNKK & $\begin{array}{ll}\text { - } 2019: \\
& \text { S4 }\end{array}$ \\
\hline
\end{tabular}

Source: 2013 - 2020 Pelan Hala Tuju Industri Jualan Langsung, Kementerian Perdagangan Dalam Negeri, Koperasi dan Kepenggunaan (KPDNKK)

This shows that it is particularly important for long-term relationships between consumers and the agents which will have high value-added to the products and services. These are one of the social factors that industry players need to consider.

Today, research has shown how an individual's personal characteristics influence their behavior, perception of risk and willingness to take risky decisions. However, the extent to which these personal characteristics influence sales agent's behavior and performance has largely remained uninvestigated in a particular context. This study tries to answer this question by analyzing the personality of individual agents particularly in the MLM industry.

The researcher literature review considered a number of topical issues: Alexander and Goh (2018) discuss career prospect, income distribution, motivation, and workplace flexibility, and its effect on working attitude. They identify a significant relationship between these attributes and concluded that the working attitude and perception of employees has become an important aspect on ensuring the organization successful. The authors observe that the perception of Generation $Y$ career option has been investigated particularly in MLM industry. However, the personalities of individual which may contribute to their working passion have attracted less research attention. Therefore, further study needs to be taken into consideration.

To expand the scope of the literature review, Roberts and Woodman (2017) identifies personalities of individual and performance as the important issue and also an emerging area of 
INTERNATIONAL JOURNAL OF ACADEMIC RESEARCH IN BUSINESS AND SOCIAL SCIENCES Vol. 10, No. 3, March, 2020, E-ISSN: 2222-6990 @ 2020 HRMARS

discussion in the context of MLM industry in which the author suggested to give more attention to personality in relation to performance.

Furthermore, the researcher highlights MLM business' role, factors and its effect on employment (Kumar \& Satsangi, 2018). The objective of this research was to study the role of MLM, to examine the factors for joining the MLM business, and to analyze the effect of MLM business on employment. The study reveals that $35 \%$ of people are unemployed in example they generate their income only from MLM business, hence it could be a substitute of full time employment. Based on the data analyzed from the previous study, MLM has significant effect on employment opportunities, this could be determined as a result. MLM is prominent business model of direct selling which is helpful in the economic and social development of country. Therefore, it is suggested to spread awareness among people.

Another relevant research paper discussed the strategies for building and retaining a productive MLM downline (Williams, 2018). The paper explores the concept of the specific business problem that some multilevel marketers lack strategies to build and retain a productive downline during the 5 years of operations. The paper draws on entrepreneurship theory and three emergent themes of strategies used by multilevel marketers to build and retain a productive downline. These themes are (1) entrepreneurial mindset, including the associated personality traits and skills; (2) strong leadership and support; and (3) training and development. According to Williams (2018), multilevel marketers who employ these strategies and train their downline in these areas can build and retain productive downline, resulting in growth and sustainability of their MLM business.

As noted earlier, the MLM industry especially the agents continue to struggle to attract people that willing to work in this profession as a productive downline. The solutions to this issue require that the root causes are identified so that remedial action can be taken to increase future participation and indirectly increase the total sales of direct selling companies. However, given the recent total sales that declined and resulted in shortages of agents in the MLM industry, indeed it is time to view this issue more seriously.

In addition, other studies have looked into the influence of personality characteristics on salespeople's performance. For example, Rothmann and Coetzer, (2003) observed the direct relationship between the personality characteristics and job performance in general. Specifically, other studies evaluated the influence of personality on salesperson's performance (Furnham \& Fudge, 2008; Hurtz \& Donovan, 2000; Smith \& Tennessee, 2000; Verbeke, 1994) in which most of them uses the big five factor model as a theoretical underpinning. It has been observed that an individual's thinking and behavioral patterns are largely determined by their personality (Allport, 1961). Eysenck (1991) suggested that personality traits are composed of five principles, namely; replicability, comprehensiveness, external correlates, source traits and multiple levels. The five principles were later renamed as the Big Five Factors (BFF) or five-factor model (FFM) which classifies personality traits into extraversion (E), conscientiousness (C), agreeableness $(A)$, neuroticism (N), and openness to experience (O).

Detailed examination of the relationship between personality, motivation and performance on key account manager context by Mahlamaki et al. (2018) showed that extraversion, agreeableness, conscientiousness, and emotional stability are found to have significant relationships to motivational constructs. The authors as well suggested that further research should include other 
INTERNATIONAL JOURNAL OF ACADEMIC RESEARCH IN BUSINESS AND SOCIAL SCIENCES Vol. 10, No. 3, March, 2020, E-ISSN: 2222-6990 @ 2020 HRMARS

motivational aspects (other behavior or skilled-related themes) that influence personality of individuals towards achieving individual's higher performance in different context. Thus, the researchers suggest the implementation of the same concept towards finding out the results of agent's performance in MLM context by using the previous study done and include the interpersonal identification as the other motivational aspect as a mediator that believe could influence individual personality towards achieving high performance of an agent. As refers to the results found by Vieira and Silva (2018), interpersonal identification as a mediator has a positive influence on sales performance and this replicated previous literature by Mullins and Syam (2014).

\section{Conclusion}

The study is in the very preliminary stage and has to be analyzed in the multilevel marketing (MLM) industry. Yet, this paper has highlighted the fact that the MLM industry in particular is confronted by productive agents' shortages. This problem is unlikely to diminish, and action is needed by practitioners and academics to create solutions that can mitigate this challenge.

This paper is proposed in order to elevate the general public awareness of what the industry is truly about. In an effort to attract and retain qualified individuals in the dynamic and exciting MLM industry, further research, new strategies and tactics must be employed. Therefore, insights from this study suggest that agents of MLM should look at their individual team member's personality traits while making recruitment decisions.

To this end, communication, collaboration and cooperation must continue to exist between academics, government and industry practitioners. The implication for positive social change is the potential to provide success strategies to current and aspiring multilevel marketers, which may result in more income generating opportunities for those who choose this path.

\section{References}

Azmi, A., Hasri, M., Nazri, A. S. A., Radzali, S., Azman, M., Abdullah, R., Jamal, I., Noor, A. M., \& Fatimah, S. (2016). Consumer Behaviour: Case Study on Avon Malaysia. International Journal of Humanities and Social Science Invention, 5(12), 31-34.

Bencsik, A., Machova, R., \& Hevesi, E. (2016). The Relation between Motivation and Personality Types. International Business Management, 10(3), 183-193.

Bhattacharjee, D. (2016). Problems and Prospects of Network Marketing in Assam (India). International Journal of Business and Management Studies, 167-182.

Blignaut, L. (2011). Personality as a Prdictor of Performance for Customer Service Centre Agents in the Banking Industry. 1-84.

Espegren, Y., \& Panicker, S. (2015). Salesperson's Personality, Motivation and Selling Performance. 140.

Franco, W., \& Gonzalez, M. A. (2016). International Expansion Opportunities for Multilevel Marketing Via Personal Networks: an Ethnographic Study from Colombia. International Journal of Business and Society, 17(1), 28-46.

Girish S. N., \& Dipa, D. (2015). Multilevel Marketing: Comparative Perspectives and Indian Dilemma. International Journal of Advanced Research in Management and Social Sciences, 105-123.

Hogan, R., \& Foster, J. (2016). Rethinking personality. International Journal of Personality Psychology, 2(1), 37-43. 
INTERNATIONAL JOURNAL OF ACADEMIC RESEARCH IN BUSINESS AND SOCIAL SCIENCES

Vol. 10, No. 3, March, 2020, E-ISSN: 2222-6990 (C) 2020 HRMARS

Hogan, J., \& Holland, B. (2003). Using Theory to Evaluate Personality and Job-Performance Relations: A Socioanalytic Perspective Journal of Applied Psychology, 88(1), 1-43.

Holloway, A. N. (2017). Sustainability of Direct Sellers in Marketing. 1-17.

Jain, S., Singla, B. B., \& Shashi, S. (2015). Motivational Factors in Multilevel Marketing Business: a Confirmatory Approach. Management Science Letters, 905-912.

Janjua, N. (2016). Impact of Personality Type on Job Productivity. Journal of Hotel and Business Management, 1-9.

Kerr, S. P., Kerr, W. R., \& Xu, T. (2017). Personality Traits of Entrepreneurs: A Review of Recent Literature. 1-37.

Kim, H. L. (2018). Factors that influence Direct Selling in the Cosmetic Market. 1-31.

Kumar, A., \& Satsangi, A. K. (2018). A study of Multi-Level Marketing Business with Specific Reference to Amway India. IRJMST, 9(3), 101-107.

Kwee, F. L., \& Kai Y. L. (2016). Towards Satisfying Distributors in Multilevel Marketing Companies. International Journal of Management and Applied Research, 3(1), 49-62.

Kwee, F. L., Teck, C. L., \& Kai, Y. L. (2016). Driving Distributors' Satisfaction in Multilevel Marketing (MLM) Companies. International Journal of Academic Research in Business and Social Sciences, 6(2), 105-120.

Mahlamaki, T., Rintamaki, T., \& Rajah, E. (2018). The Role of Personality and Motivation on Key Account Manager Job Performance. Industrial Marketing Management, 1-11.

Mather, R. D., Belden, D., \& Sherwood, H. (2017). Social Cognitive Factors of Persuasion for Multi-. Journal of Scientific Psychology, 44-51.

Miller, C. R. (2015). Depth of a Salesman: Exploring Personality as a Predictor of Sales Performance in a Multilevel Marketing Sample. All Theses, Dissertations, and Other Capstone Projects, 1-37.

$\mathrm{Ng}$, K. L. (2015). Factors Influencing Consideration on Multilevel marketing (MLM) Enrollment. 1-122.

Pelan Hala Tuju Industri Jualan Langsung Mengemudi Masa Hadapan Jualan Langsung. (2013-2020). Kementerian Perdagangan Dalam Negeri Koperasi dan Kepenggunaan.

Roberts, R., \& Woodman, T. (2017). Personality and Performance: Moving Beyond the Big 5. Current Opinion in Psychology, 104-108.

Santiago, J. R. D. (2016). A Study of Direct Selling in the Philippines: Marketing Strategies for the Sustainability of Direct Sellers.

Sulong, R. S., Caneza, C., \& Geetha, C. (2017). Factors influencing Intention to become Avon Dealers: a Case Study in Sandakan, Sabah. Proceedings of International Conference on Economics 2017 (ICE 2017), 357-376.

Statistik Utama KPDNKK April. (2018). Bahagian Perdagangan Dalam Negeri.

Tay, G. M., \& Goh, P. J. (2018). Malaysia Generation Y's Perceptions and Attitudes towards Multilevel Marketing (MLM) Career Option. Journal of Humanities, Language, Culture and Business (HLCB), 2(8), 162-171.

Tyre, T. A. (2016). Network Marketing Essence of Success: an Interpretative Phenomenological Analysis. 1-12.

Ulucam, S., Unusan, C., \& Canbolat, M. A. (2016). Achievement of Distributors in Multi-Level Marketing and an Analysis of Factors Affecting Work Satisfaction. Full Paper Proceeding BESSH 156(10), 1-12. 
INTERNATIONAL JOURNAL OF ACADEMIC RESEARCH IN BUSINESS AND SOCIAL SCIENCES

Vol. 10, No. 3, March, 2020, E-ISSN: 2222-6990 @ 2020 HRMARS

Vieira, V. A., Silva, J. D. D., \& Gabler, C. (2018). The Power of Organizational Prestige in Optimizing Sales Performance. Marketing Intelligence \& Planning.

Williams, R. (2018). Strategies for Building and Retaining a Productive Marketing Downline. Walden Dissertations and Doctoral Studies, 1-83.

Youshan, B., \& Hassan, Z. (2015). The Effect of Employees Personality on Organizational Performance: Study on Insurance Company. International Journal of Accounting and Business Management, 3(1), 187-194.

Zhou, M. (2015). Moderating effect of self-determination in the relationship between Big Five personality and academic performance. Personality and Individual Differences, 385-389. 